\title{
Social participation in designing urban spaces related to green areas on the example of Białystok
}

\author{
Kamil Rawski \\ https://orcid.org/0000-0002-3845-4556 \\ k.rawski@pb.edu.pl \\ Faculty of Architecture, Bialystok University of Technology
}

\begin{abstract}
Social participation is a tool thanks to which newly designed places can be adapted to the needs of residents as much as possible. People can also decide to extend the functional program of the housing estates where they live. Therefore, this phenomenon has a real influence on shaping their close surroundings. The article analyses how social participation takes place in Bialystok on the example of the Civic Budget organized by the Municipal Office.
\end{abstract}

Keywords: social engagement, participation, Bialystok, Civic Budget, land development

\section{Introduction}

The sense of connection with the place of residence has various meanings for people, which may manifest in the form of local patriotism that they share with their neighbors. One of the levels of the spatial and social structure of the world is formed by the inhabitants of settlement units together with a given place, i.e. e.g. a city district. Such a community is shaped by collective contacts of people (not necessarily personal) and at least a superficial knowledge of the place [Pawłowska 2001]. The ability to have an influence on various decisions of the authorities in matters concerning residents strengthens their sense of belonging and gives them causative power. Therefore, social engagement refers to the participation of individuals in collective activities undertaken in the communities to which they belong or in which they live every day. The right reference frames is, in this case, the idea of civil society [Kaźmierczak 2011].

Participation is not limited to information but is primarily interactive. It is also not a random activity, but a consciously organized process of involving citizens. Thanks to this, they gain a certain level of influence on the decisions they make [Kaźmierczak 2011].

\section{Material and methods}

In the article, there was searching for a way in which social participation influences the city's landscape and contributes to the creation of new places, in particular, those that are related to green areas. The study was conducted on the example of the Bialystok city, where the Citizens' Budget (in polish: Budżet Obywatelski) has been carried out annually for several years. The whole process is public and the City Hall provides on its website information on implemented projects in individual editions of this initiative. Based on the obtained data, the projects were classified according to their type to show the strength of impact and possibilities of influencing that the inhabitants of Białystok both on the view of their nearest neighborhood locally and on the city scale. The submitted projects were divided into a housing estate and municipal. However, in this study, it was 
decided to collectively summarize all implementations regardless of the project's scale, while the differentiation criterion was the type of investment and its purpose.

\section{Results and discussion}

\section{Social participation}

The concept of social engagement means the participation of citizens in managing the affairs of the community of which they are members. Therefore, it is difficult to talk about maintaining harmony between spatial and social development of a place without allowing residents to co-decide on its spatial development. Local government activists organizing people's participation in spatial projects contribute to the sense of inhabitants' familiarity with a given area in the same way as an architect designing a house, urban planner shaping a square, or sculptor creating a monument [Pawłowska 2001].

An important goal of participation is to involve future users in the specific design process. It requires some effort made by local authorities in cooperation with experts, but the successful participation of residents in designing brings many benefits. Members of the community should be invited to engage in the early stages of design because their participation only after all-important decisions could be considered dismissive. Experts should prepare many different variants of solutions to choose from and reveal the scope of their capabilities so that quick actions can be taken. For future users participating in the design process to have a good idea of the new appearance of space, it is good to use visual or spatial materials showing design solutions [Bell et al. 2004].

In Poland, many different instruments and techniques are using to involve citizens in deciding on public matters. To order such forms of participative tools, the following divisions were introduced:

- due to the base for taking action by public authorities:

a. obligatory - public authorities have their constitutional or statutory obligation to use them,

b. facultative - used as a supplement to mandatory tools or to improve the quality of public management, their use depends on public authorities,

- due to the implementation method and used techniques:

a. based on traditional institutions of direct democracy (e.g. referendum, access to public information, institution of complaints and requests, meetings and public debates),

b. innovative, using communication and participation methods specific to the enterprise sector (customer-oriented), using new communication techniques (ICT), or using modern research techniques [Noworól et al. 2012].

K. Pawłowska [2012] in her article Partycypacja społeczna w podejmowaniu decyzji dotyczących przyrody w mieście (en: Social participation in making decisions about nature in the city) describes the basic forms of participation, dividing the whole process into 5 phases:

- Phase 1 - informing stakeholders

$\square$ Public information sharing alone may not be sufficient to effectively interest the local community. Good practice in this case is modeling on commercial advertising and using information forms appropriate for a specific target group.

- Phase 2 - pre-project analysis of needs

$\square$ Badania społeczne nie mogą ograniczać się jedynie do przeprowadzenia ankiet. Powinno stosować się metodykę odpowiednią do oczekiwanych rezultatów, dlatego też np. przeprowadzanie warsztatów projektowych będzie lepszą metodą w przypadku chęci pozyskania inspiracji niż wypełnianie ankiet.

Phase 3 - project presentations and explanations

$\square$ Just meeting the legal requirements to make individual documents available for review does not guarantee the effectiveness of starting a dialogue with stakeholders. It is also good to explain the plans so that they should be understood by non-professionals. The presenting person should be well prepared for the presentation and explanation of the project. 
Phase 4 - public discussion

$\square$ Discussions should take place not under pressure of conflicts, but on the initiative of local authorities with the participation of a mediator who wants both parties to reach an agreement. Lack of knowledge in the field of social communication in people conducting such discussions can only cause the escalation of conflicts.

Phase 5 - negotations

Compromise is not the best result of negotiations, because in this case, both sides must give up something. Therefore, a win-win agreement should be sought. For negotiations to take place in an atmosphere of mutual respect, it is worth inviting a competent mediator to them.

The implementation of the individual phases is directly related to the use of tools used in social participation, among which can be distinguished:

- studies,

quantitative methods,

qualitative methods,

- debates,

workshops ${ }^{1}$.

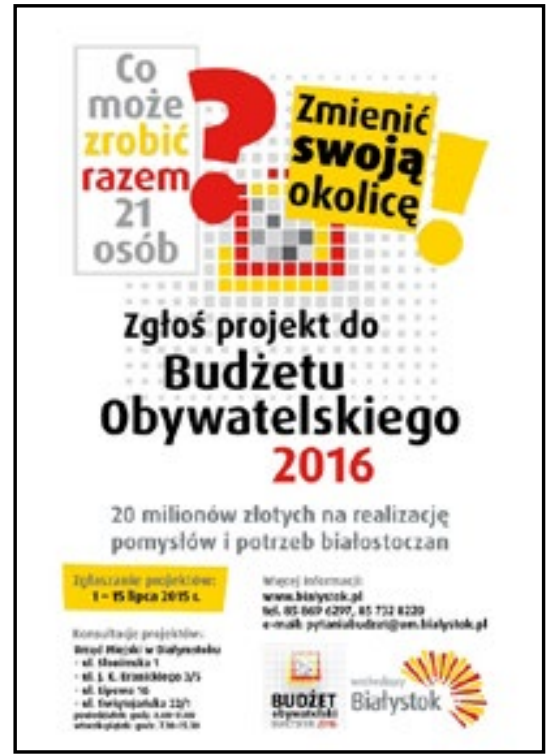

Fig. 1. Leaflet encouraging to submit the project to the civic budget (source: http://www.bialystok.pl/pl/wiadomosci/ aktualnosci/bialostockie-centrum-konsultacji.html)

Conducting research is mainly aimed at understanding the needs and opinions of the local community that are related to selected issues. Studies are mostly conducted in many forms. Those are surveys, polls, and interviews using paper or electronic questionnaires. They can be also conducted in oral form. Quantitative methods are used to collect data that allows answering the question "how much?". They tell us among others, whether the idea has more supporters or opponents. Qualitative methods, on the other hand, rely mainly on observation and searching for causes and motivations. It is also practiced that studies are mixed and carried out by combining both methods. Thanks to the debates, it is possible to find out the opinions of its participants during discussions on a given topic. They are mostly in open forms and experts associated with a given issue are invited to it. Workshops, on the other hand, are used to involve the community in practical aspects such as developing an action plan or visions of desired changes. Very rarely the authorities limit themselves to choosing only one tool because greater effectiveness in participation is obtained by combining them in various combinations, e.g. debates + studies, workshops + debates, etc. and in particular, using all the tools consecutively according to a specific schedule. 
Initiatives like the civic budget are good examples of involving residents in the space planning process (Fig. 1). Therefore, citizens can submit their projects for consultation and consideration, and those with the most votes will be implemented. A specific amount of money is allocated for implementation to be used in housing estate and city-wide projects.

\section{Participation in Białystok}

The Civic Budget is an initiative under which the inhabitants of Białystok decide about the allocation of part of the city's budget. They have the opportunity to submit proposals of their projects for implementation and then they can vote for them. Therefore, it is a form of facultative participation organized by local authorities. As part of the Bialystok Civic Budget, since 2013 it is possible to submit projects belonging to the city's or district's tasks, having a city-wide or housing estate character2. Moreover, they should be located in the area belonging to the municipal.

Projects submitted to the budget of 2020 had to have the support of at least two city residents, which is a significant simplification compared to previous years, where it was required a minimum of 20 . It is worth noting that the preparation of the city resolution draft about the particular editions of the Civic Budget also takes place on the road of social consultations at the very beginning. After the resolution comes into force, residents are informed about the upcoming possibility of submitting their projects via the website and leaflets.

Then, the recruitment process is carried out simultaneously with the public consultation. In recent years, information and educational meetings with the inhabitants of Bialystok have been held several times and in various places, during the period intended for submitting and consulting projects. Most often in the second quarter of the year to which the given edition of the Civic Budget concerned. Special consultation points serviced by the employees of the office are available in the buildings of the Municipal Office in Bialystok. There are also organized so-called marathons for writing applications, i.e. events where people are encouraged and supported to submit a project almost all day long.

\begin{tabular}{|c|c|c|c|c|c|c|c|}
\hline & 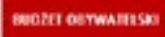 & 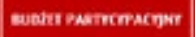 & 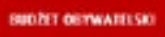 & gerea astwamsa & Baezt obTwarase & Bovert obrwatess & Brozer obrwarase \\
\hline & 2014 & 2015 & 2016 & 2017 & 2018 & 2019 & 2020 \\
\hline PRZLZNACZONA KWOTA & $10 \mathrm{mln}$ z! & $12 \operatorname{mln} x$ & $20 \mathrm{mln} d$ & $10 \mathrm{mln}$ zt & $10 \mathrm{mln}$ at & $10 \mathrm{mln} z$ & $12 \mathrm{mln}$ at \\
\hline \multirow{5}{*}{$\begin{array}{l}\text { ULCZBA PROIIETOW } \\
\text { ZWKWALFIKOWANYCH } \\
\text { DO GLOSOWANLA }\end{array}$} & \multirow{5}{*}{51} & 56 & 57 & 62 & 44 & 93 & 90 \\
\hline & & 24 & 28 & 25 & 17 & 16 ogólnomiejskich & \multirow{2}{*}{29 ogólnomiejskich } \\
\hline & & duze & ogbinomiejskich & ogólnomiejskich & ogólnomiejskich & 36 osiedlowych & \\
\hline & & 32 & 29 & 37 & 27 & 33 oswiatowe & \multirow{2}{*}{61 osiedlowych } \\
\hline & & mate & osiedlowych & osiedlowych & osiedlowych & 8 zielonego budietu & \\
\hline \multirow{5}{*}{$\begin{array}{l}\text { IICZBA PROJIKTOOOW } \\
\text { RFKOMFNDOWANYCH } \\
\text { DO RFALIEACJ! }\end{array}$} & \multirow{5}{*}{7} & is & 39 & 29 & 36 & 27 & 32 \\
\hline & & 4 & น8 & 7 & $\mathbf{n}$ & 8 œ ólnomiejskich & \multirow{2}{*}{11 ogölnomiejskich } \\
\hline & & dute & ogolnomiejskich & ogólnomiejskich & ególnomiejskich & 10 osiedlowych & \\
\hline & & 11 & 21 & 22 & 25 & 8 oswiatowych & \multirow{2}{*}{21 osiedlowych } \\
\hline & & matych & osiedlowych & osiedlowych & osiedlowych & 1 zielonego bodzetu & \\
\hline $\begin{array}{c}\text { PROJFKIY } \\
\text { ZREALILOWAME }\end{array}$ & 7 & 14 & 36 & 26 & 26 & 4 & , \\
\hline
\end{tabular}

Fig. 2. Table showing the number of projects submitted in subsequent editions (source: Materials shared by City Office of Białystok in presentation that presents results of Civic Budget 2020 on their website).

The next step is the verification of the projects and the announcement of qualified projects that people can vote for. At the same time, a promotional campaign is starting to encourage residents to vote for selected 
projects. In recent years, a festival has also been organizing where the originators could encourage the selection of their projects. Each resident can vote on the internet or by paper form. Through the last few years, as a result of this initiative, many projects were implemented, as shown in the table below (Fig. 2).

The projects concerned many aspects of citizens' lives. They can be included in the following categories:

- communication - projects aimed at renovation, modernization, extension or construction of new pavements, bicycle paths, parking lots or roads;

- cultural events - that is, the organization of various types of social, cultural, educational or sporting events;

- land development - projects related to green areas as well as sport and recreation;

- sports facilities - single sports facilities such as fields or an outdoor gym;

- other - projects that cannot be assigned to the above categories (eg related to the city's history or health protection).

Below, it is presented a chart with the participation of individual categories of projects that qualified for implementation in the 2016-2020 editions, compared to their overall number.
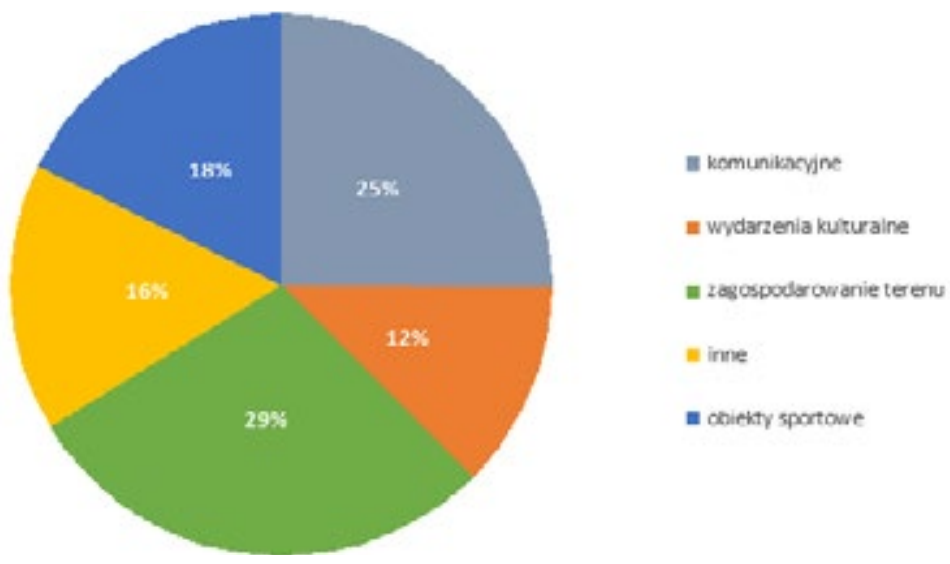

Fig. 3. Percentage share of individual projects qualified for implementation in the 2016-2020 editions (source: Prepared by author basing on data shared by City Office of Białystok).

Based on this pie chart, it can be stated that projects aimed at developing a specific area represent the largest percentage of all projects submitted, followed by projects related to improving communication. However, taking into account the trend in reporting the number of individual projects (Fig. 4), it can be concluded that the number of projects that would need the knowledge of landscape architects at the consultation stage may increase even more.

Reducing the number of required signatures to submit the project is a big simplification. For example, it is enough to have the support of the closest family (and fulfill the requirements from resolution) to have a chance for the second stage. It happens probably to encourage residents to submit more projects. But on the other hand, the quantity will not always result in the quality, and the question arises if the entire amount of budget should always be spent, or maybe it would be better to focus on developing the best ideas. For this purpose, it would be helpful to introduce some certain conditions that must be met in order for the project to be implemented (submitted to tender). Of course, it is difficult to talk about all projects here, but it happens that a relatively small group of people in the city scale decides about the implementation of the given project, regardless of whether deeper analyzes would show its validity. A good example is the construction of 16 petanque tracks in a poor functional arrangement in Fredro Park. 946 people supported this investment amounting to 205,000 zł. It was enough for it to be implemented, while only 2 or 3 such tracks could be enough, and the rest of the area could be arranged (and money spent) differently. There are also cases where the number of votes even below 200 (e.g. 164 in 2016 or 116 in 2017) determined the qualification of a given project for implementation.

Despite all, the amount of work put into activating the society and encouraging it to participate brings not only many benefits but also opportunities to improvement of relations with local authorities and improve their functioning through cooperation. Such integration serves the mutual recognition of limitations and new possibilities. 


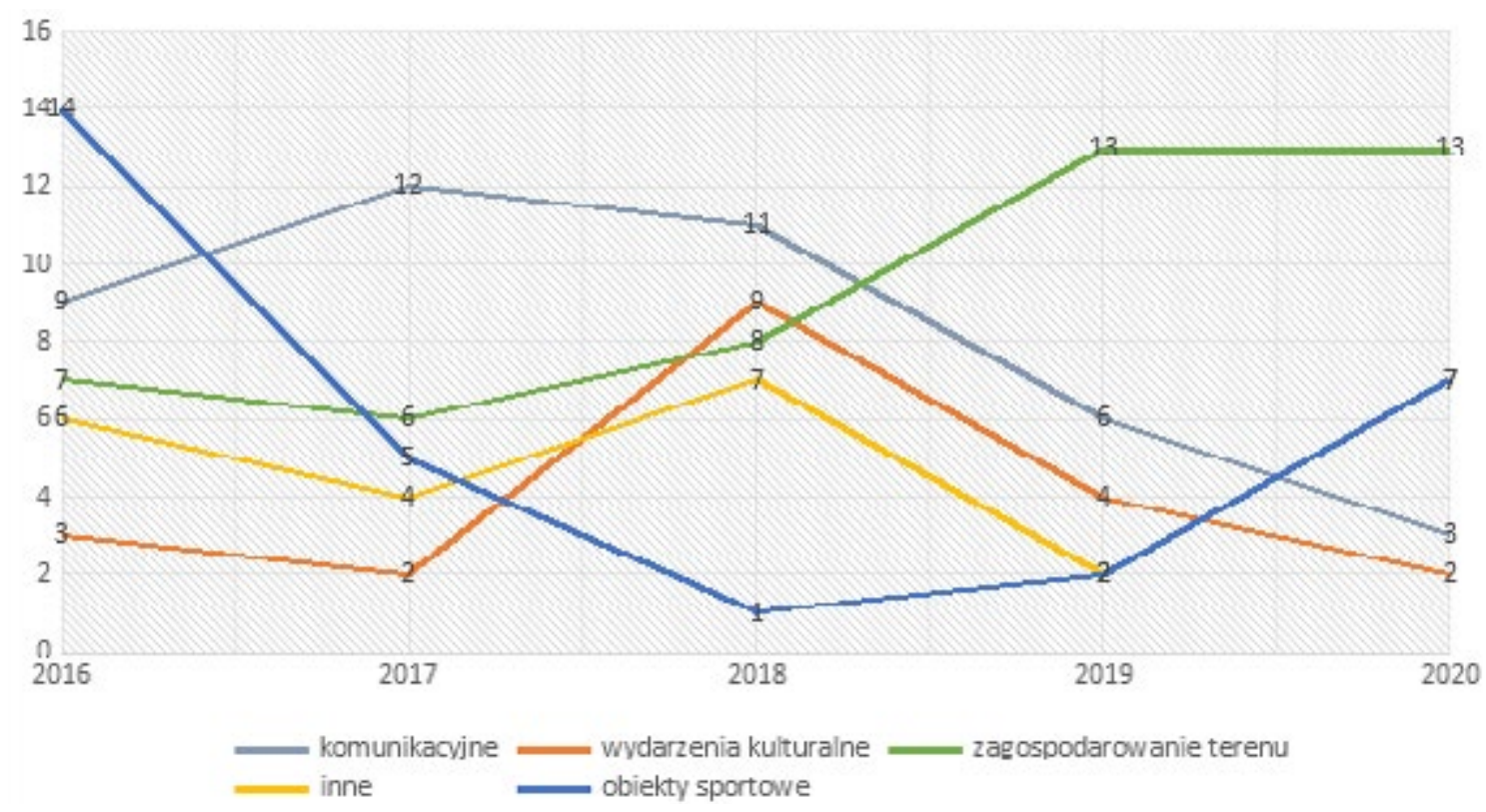

Fig. 4. Change in the number of qualified projects over subsequent editions (source: Prepared by author basing on data shared by City Office of Białystok).

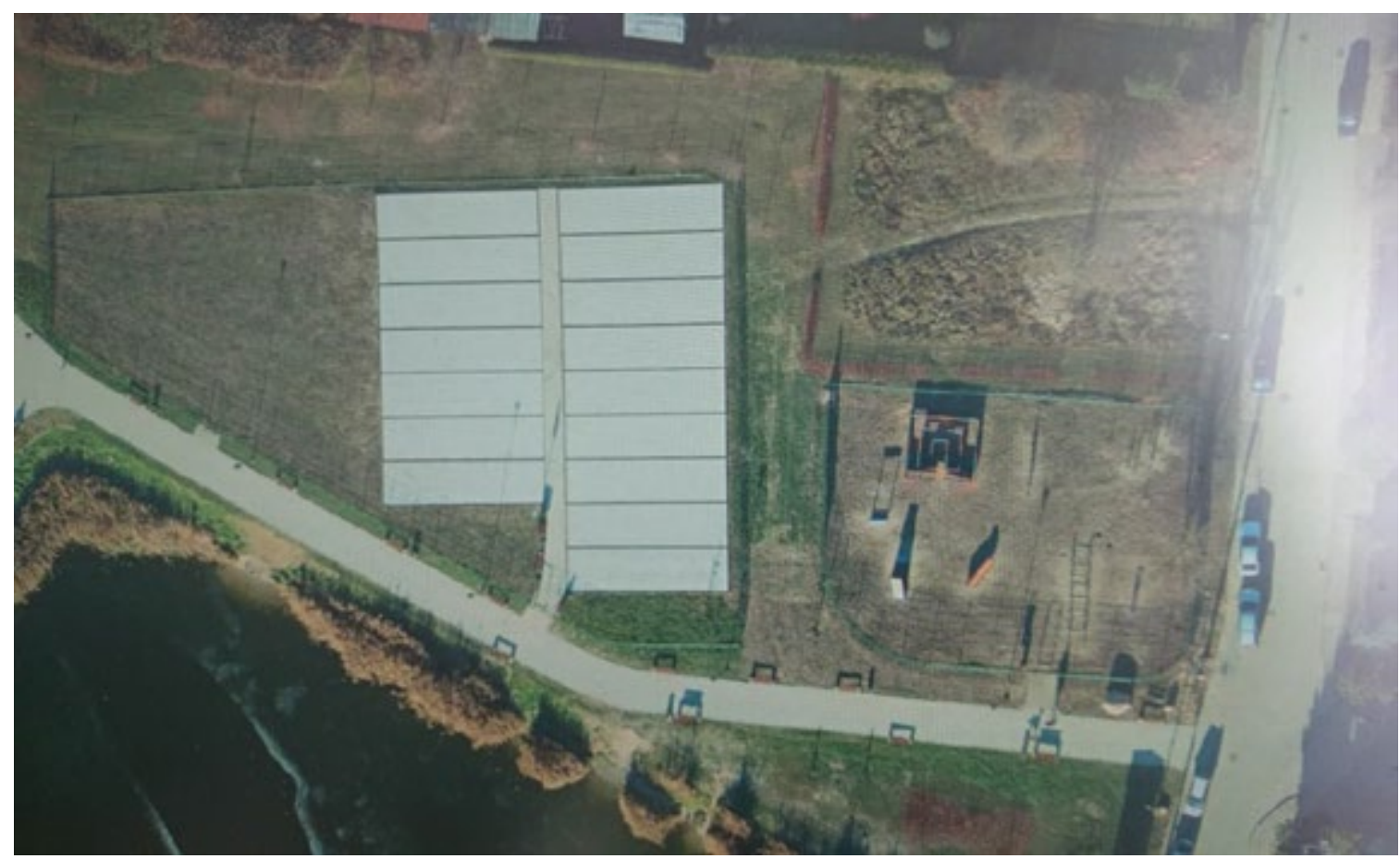

Fig. 5. Boule tracks in Fredro Park (source: gisbialystok.pl).

By including the area's inhabitants in planning, it is possible to use their practical knowledge, as well as their inspiration and ideas. On the other hand, the authorities can explain their intentions more effectively and learn about the residents' reaction to the proposed changes. Designers have a chance to better understand the needs of future users, so they can better adapt space to them. The opportunity to participate in the design process also contributes to greater acceptance and increased public confidence in current and future projects. 
Educated over time, residents can participate more and often in the plans of local authorities, which is conducive to the development of civil society. Whereas, public information about enterprises reduces the phenomena of corruption, nepotism, cronyism or manipulation [Pawłowska 2008]. The possibility of social consultation of local problems is conducive to their identification and increases the probability of developing accurate and socially acceptable decisions aimed at a constructive solution to such problems. Improving the dialogue between local authorities and the community significantly limits the rising of conflicts, promotes the activation of society and ultimately contributes to the increase of the resident's quality of life [Kwiatkowski 2003].

People involved in the process of social participation also acquire knowledge about the competences of individual city departments and institutions that can help them in solving various problems [Zając 2014].

\section{Conclusion}

The local community, due to their daily functioning in a given area, has a broad view on many issues that concern it. The sooner residents are included in the space planning process, the better. It is good to encourage people to get involved in transforming space as soon as possible, thanks to which they will increase their sense of community and responsibility for a given place [Project for Public Spaces 2000]. Social participation is, therefore, a tool thanks to which newly designed places can be adapted to the needs of residents as much as possible.

However, if people have a free hand, they will not always be aware of their needs or may not know what the possibilities of transforming their environment are. They also often look through the prism of local trends, as it is good illustrated by the "mass production" of subsequent outdoor gyms. As a result, many such places become empty over time. Therefore, it can be stated that meetings with experts in the field of space design at the initial application stage would help to make a project that is better adapted to the needs of a given group (and at the same time going by the principles of composition and aesthetics). Examples are the designs that for example, have been created in cooperation with landscape architects since the very beginning. They are well thought out, not only when there is a space with a larger area for development. Creating a place design as a result of an invitation to tender does not necessarily have to bring the same effects as in the case when more guidelines would have been established in the earlier stages of the project in cooperation with specialists. On the other hand, architects and designers who lived in the space covered by the Civic Budget, also have the opportunity to submit the design just like any other citizen. Perhaps their engagement in this area (on a micro and macro scale) would contribute to improving the city's image.

Note. The article was prepared in frames of the statutory work S/WBilS/2/2016 realized by WA, PB.

\section{References}

[1] Bell P. A., et al., 2004. Psychologia Środowiskowa, Gdańskie Wydawnictwo Psychologiczne, Gdańsk.

[2] Ferens A., et al., 2010. Jak prowadzić konsultacje spoteczne w samorządach? Zasady i najlepsze praktyki wspótpracy samorządów z przedstawicielami społeczności lokalnych - Przewodnik dla samorządów, Fundacja Rozwoju Demokracji Lokalnej, Warszawa.

[3] Hausner J., et al., 1999. Komunikacja i partycypacja społeczna, Małopolska Szkoła Administracji Publicznej Akademii Ekonomicznej, Kraków.

[4] Kaźmierczak T., 2011. Partycypacja publiczna: pojęcie, ramy teoretyczne [w:] „Partycypacja publiczna, O uczestnictwie obywateli w życiu wspólnoty lokalnej”, red. A. Olech, Instytut Spraw Publicznych, Warszawa, s. 83-99.

[5] Kwiatkowski J., 2003. Partycypacja społeczna i rozwój społeczny, Agencja Wydawniczo-Reklamowa MT, Warszawa.

[6] Lorens P., Martyniuk-Pęczek J., 2010. Problemy kształtowania przestrzeni publicznych, Wydawnictwo Urbanista, Gdańsk.

[7] Noworól A., Noworól K., Hałata P., 2012. Partycypacja społeczna w zarządzaniu procesami rewitalizacji, [w:] „Problemy Rozwoju Miast", Nr 1/2012, Instytut Rozwoju Miast, Karków, s. 26-39.

[8] P. Frączak P., 2010 Prawne i polityczne aspekty roli organizacji pozarządowych w rozwoju lokalnym [w:] „Partycypacja społeczna i aktywizacja w rozwiązywaniu problemów społeczności lokalnej", red. B. Lewenstein, J. Schindler, R. Skrzypiec, Wydawnictwo Uniwersytetu Warszawskiego, Warszawa, s. 42-62. 
[9] Pawłowska K., 2001. Idea swojskości miasta, Wydawnictwo Politechniki Krakowskiej, Kraków.

[10] Pawłowska K., 2008. Idea i metody partycypacji społecznej w architekturze krajobrazu, [w:] „Prace Komisji Krajobrazu Kulturowego", Nr 10, Komisja Krajobrazu Kulturowego PTG, Sosnowiec, s. 617-624.

[11] Pawłowska K., 2012. Partycypacja społeczna w podejmowaniu decyzji dotyczacych przyrody w mieście, [w:] „Zrównoważony Rozwój - Zastosowania" nr 3/2012, Fundacja Sendzimira, Kraków 2012, s. 51-70.

[12] Project for Public Spaces, 2000. How to Turn a Place Around: A Handbook for Creating Successful Public Spaces, Project for Public Spaces, New York.

[13] Zając A., 2014. Partycypacja mieszkańców w procesie rewitalizacji osiedla [w:] „Kształtowanie współczesnej przestrzeni miejskiej", red. M. Madurowicz, Wydawnictwo Uniwersytetu Warszawskiego, Warszawa, s. 218-227.

\section{Websites}

[1] http://partycypacja.fise.org.pl/x/760749 (dostęp: 13.02.2017)

[2] http://partycypacja.fise.org.pl/x/777930 (dostęp: 13.02.2017)

[3] http://pspe.gridw.pl/?id=11 (dostęp: 13.02.2017)

\section{Partycypacja społeczna w projektowaniu miejskich przestrzeni związanych z terenami zieleni na przykładzie Białegostoku}

Streszczenie: Partycypacja społeczna jest narzędziem, dzięki któremu nowo projektowane miejsca mogą być w jak największym stopniu dopasowane do potrzeb mieszkańców. Ludzie mogą również decydować o rozszerzeniu programu funkcjonalnego osiedli, na których mieszkają. Zjawisko to ma więc realny wpływ na kształtowanie ich najbliższego otoczenia. W artykule przeanalizowano sposób w jaki partycypacja społeczna odbywa się w Białymstoku na przykładzie organizowanego tam przez Urząd Miasta Budżetu Obywatelskiego.

Słowa klucze: partycypacja społeczna, Białystok, Budżet Obywatelski, zagospodarowanie terenu 